\title{
THE POLTICS OF ENVIRONMENTAL DISPUTE RESOLUTION
}

\author{
Barry G. Rabe \\ University of Michigan at Ann Arbor
}

Few spheres of American domestic policy are as riddled by confilct or as dependent upon the judiciary for direction as environmental policy. In fact, the frequency and intensity of conflict have created a policy making void that the judiciary has, for better or worse, filled. Given the incapacity of executive and legislative branches of government to resolve such fundamental disputes, the courts have become a dominant force in American environmental policy. ${ }^{1}$

Court-shaped policy, however, is suspect in terms of its capacity to protect human health, limit interference with economic growth, and stimulate the search for innovative methods to improve environmental quality. And it has attracted a host of critics in recent years, many of whom question the basic ability of courts to make competent decisions on science-oriented matters.

The growing unrest over our judicially-dominated environmental policy system has led to the exploration of alternative approaches to resolving environmental conflicts. These approaches include mediation, regulatory negotiation, and policy dialogue. Many of these are intended to mitigate conflict through direct and systematic interaction among disputants. Rather than delegate dispute resolution to a judge, jury, or arblter, these alternatives force varying parties to design their own solutions, with policy reflecting group consensus rather than judicial decree.

In theory, these approaches offer ways to forge a style of environmental policy that is more cooperative and effective. And in practice, there are considerable grounds for optimism on both counts. Other spheres of domestic policy, including labor and management relations and special education, have long relied on comparable approaches that were generally deemed effective. Even in conflictriddled environmental policy, a growing number of disputes have been at least partially resolved through utilization of such approaches.

These initial experiments have resulted in an outpouring of publications on "environmental dispute resolution" (EDR). Many of these chronicle one or more environmental conflicts that were resolved through mediation or a related approach. Most are extremely enthusiastic about the potential of EDR and few perceive any significant impediment to vast expansion in its use or any significant policy shortcoming if it were to be widely employed. 
This paper is intended to inject a sense of balance into the current search for alternatives to judicially-dominated environmental policy. It recognizes the considerable potential of EDR but suggests that it is best viewed as a possible regulatory reform rather than a proven alternative that can and should transform environmental policy. The rationale for EDR in the current conflict-ridden climate and an assessment of its considerable promise will be explored in greater detail. However, most of the paper will examine possible obstacles that any effort to expand EDR may face given the realities of American politics. It will also question the potential capabilities of EDR to deliver more effective environmental policy, even if these political hurdles can be cleared.

\section{THE PENCHANT FOR CONFUCT AND THE PURSUIT OF ALTERNATIVES}

The American political system is poorly-equipped to resolve conflicts when passions run deep and interests are well-entrenched on both sides. Such problems are rare in distributive or developmental policies, in which elected officials are only too happy to authorize revenues or services for designated constituencies. But they are common in redistrlbutive or regulative policies, where some constituencies are likely to be disadvantaged by any decision. This is particularly evident in the context of environmental policy, where the economic and social stakes are quite high and a compromise position is rarely apparent.

Elected officials are likely to balk at resolving conflicts in such situations. They may try to placate pro-regulation constituents with legislation that is symbolically impressive but not overly-threatening to anti-regulation constituents (such as the Toxic Substances Control Act). Or they may transform regulatory policies into distributive policies by directly funding most of a mandated cleanup activity (such as the Water Pollution Control Act). But they will enter fundamental conflicts with considerable trepidation and will be, in all likelihood, only too happy to defer to the judiciary on such matters.

Congress has in fact encouraged shifting of decisions that it might have made to the judicial realm with the expansive definitions of legal standing and broad citizen suit provisions included in many major pieces of environmental legislation. As a comparative analysis of environmental policy in American and other industrial nations concluded, "U.S. law erects the lowest entry barriers against both associations and individuals wishing to challenge administrative decisions" (Brickman, Jasanoff and llgen, 1985:109). The ever-growing body of pressure groups that have formed around environmental issues has seized this opportunity to challenge virtually every aspect of 
environmental policy. These groups represent both pro- and antiindustry forces and take advantage of the relatively lower costs of trying to shape policy through legal challenge instead of legislative lobbying. As a result, many of the major environmental policy conflicts--from interpretation of the Clear Air Act to siting a hazardous waste facllity in a particular community--must ultimately be resolved by the judiclary. As former Environmental Protection Agency Administrator Willam Ruckelshaus (1984) has explained, federal environmental officials generally assume a tentativeness to any action that they might take since approximately four of every five rules promulgated by the agency are challenged by suits.

This pattern is consistent with the historic American reliance on dispersal of power among branches of government and distrust of ceding European-style authortty to the agencies responsible for carrying out regulatory leglslation (Price, 1983; Heclo, 1977). It also follows a growing American tendency to resolve fundamental policy problems through litigation. As Jethro Lieberman (1981) has observed, America has become a "litigious society," and he uses litigation-laden environmental policy as a cornerstone in defending his thesis.

\section{The Doubts Concerning Judicial Capacity}

Judicial domination of spheres of domestic policy would probably not be very controversial if there were not doubts over the capacity of courts to make timely, informed, and balanced decisions. But once one dispenses with the aura of judicial mystique that long dominated social science accounts of judicial behavior, a very serious set of questions must be explored. In fact, a growing number of criticisms have been raised in recent years that pose basic challenges to the ability of courts to confine themselves to appropriate areas of intervention and effectively address complex issues.

At one extreme, critics assert that judges have aggressively sought to fill the political void in dealing with controversial issues. Full-blown theories of "judicial imperialism" are rare, but a charge of judiclal overzealousness in various policy areas is rather widespread. This aggressiveness is seen as particularly dangerous in instances where courts move beyond resolution of a specific dispute and begin to engage in far-reaching policy analysis, as they have in "mass toxic tort" cases such as Agent Orange (Schuck, 1987:4).

Courts have also become suspect in terms of their basic competence to deal with the kinds of highly-technical issues that are so common in environmental cases. Not only are courts burdened with the host of cases requiring conversance with a wide range of policy issues, but few judges or clerks are trained in the scientific and related methodological skills needed to develop a basic understanding of many cases. Most judges are legal generalists and many were 
trained before environmental law became a fairly common elective in legal education.

Courts may also have unusual difficulty in dealing with environmental cases because they deviate from the bi-polar pattern that is common in many other dispute areas and for which they are best suited. Consistent with Lon Fuller's (1981) doctrine of "polycentrism," courts are poorly equipped to sort out the competing claims of more than two parties. Environmental cases commonly involve three or more parties, consistent with the multiplicity of agencies and pressure groups active in environmental policy. According to $R$. Shep Melnick (1983:61), they adhere to the model "that legal scholars for years claimed was not appropriate for judicial resolution."

The absence of environmental policy expertise and the proliferation of participating parties further explains the rather inconsistent, ad hoc way in which many environmental cases are decided. Melnick (1983:61) has detected considerable variation in cases concerning the Clean Air Act, finding that different U.S. Circuit Courts interpret the Act in very different ways. Even within a single environmental case, a change in presiding judges in mid-case can result in a radically different interpretation of the proper role of the court and outcome (see, for example, Schuck, 1987:113).

Uninformed, inconsistent decisions can obviously have serious policy consequences. But the basic process of a court-based approach to dispute resolution may have adverse policy ramifications regardless of the quality of the ultimate decisions. The reliance on adversarial procedures leads disputants to take extreme positions and may destroy any prospect of a reasonable central ground. According to Gregory Daneke, "Court rulings have reinforced that adversarial relationship, and in some cases prevent any type of consultation between parties from taking place" (Daneke, 1984:145; Downing, 1983).

Strong reliance on courts to shape environmental policy may thus prove extremely expensive, both in terms of implementation inefficiencies and the laborious process of resolving disputes. In the absence of an overarching political or social consensus, each challenge must be hammered out separately, involving all of the direct costs of operating courts as well as the far greater long-term costs of delay and indecision. These factors may help to explain why the costs of implementing environmental programs are significantly greater for government and industry in the United States than Western European nations, although there is minimal discernible difference in the environmental and public health impacts of these regulatory programs (Brickman, Jasanoff and llgen, 1985; Vogel, 1986). 


\section{THE SEARCH FOR ALTERNATIVES}

These doubts surrounding judicial capacity to forge coherent, effective environmental policy have triggered a search for dispute resolution alternatives in recent years. Non-litigative methods for dispute resolution are not new, but only in recent years have they been utilized with any frequency in American environmental issues. In theory, these various methods are linked by their emphasis on bringing contending parties together to explore possible settlements. This may Involve mediation of a speclific environmental controversy, such as the authorization of water quality permits at a single manufacturing plant. It may also address broader issues, as in a policy dialogue in which a neutral convener will help a large number of interested parties chart long-term strategles for environmental policy.

As recently as a decade ago these EDR approaches were clearly confined to the fringes of American environmental policy. Few EDR cases had been undertaken, much less resolved, and virtually no research had been conducted. This was in vivid contrast with several other areas of domestic policy in which dispute resolution alternatives were well established and the overall role of the judiciary more subdued. It was also in contrast with the practices of many other Western democracies, including most nations of Western Europe, in which the courts have far less influence in environmental and other areas of domestic policy and more consensual processes of dispute resolution are well established.

But EDR has clearly gained a foothold in American environmental policy since the mid-1970s and gives every indication of being utilized in more environmental conflicts in future decades. One of the major forms of EDR has been mediation, as the number of environmental disputes that have been mediated increased from nine in 1977 to 161 by mid-1984. These disputes have involved a wide array of environmental issues and 78 percent of them have reached some form of agreement (Bingham, 1986:7-8, 32-33, 73). Far-reaching policy dialogues have attained some degree of consensus in complex areas such as coal development and groundwater protection. And federal regulatory agencies, including EPA, the Occupational Safety and Health Administration, and the Federal Aviation Agency, have begun experimentation with "regulatory negotiation," a form of negotiated rulemaking that seeks to develop a consensus among contending parties in place of prolonged legal challenges to agency-proposed rules (Gusman and Harter, 1986; Susskind and McMahon, 1985).

EDR is also beginning to be used on more than an ad hoc basis. Six states have institutionalized some form of mediation in the siting of hazardous waste facilities before parties may pursue arbitration or Iftigation. $^{2}$ Five states have established statewide mediation offices, 
funded in part by the National Institute for Dispute Resolution, that assist states in providing mediation services for environmental and other conflicts. ${ }^{3} \mathrm{~A}$ number of other states are considering additional measures that attempt not only to increase the frequency with which EDR is used but also to formally embrace it as a preferred alternative to court-resolved disputes.

\section{THE POSSIBLE SHORTCOMINGS OF ENMPONMENTAL DISPUTE RESOLUTION}

Environmental dispute resolution has acquired a certain acceptability in environmental policy circles, having been embraced by such mainline environmental organizations as the Conservation Foundation and ihe National Wildife Federation. Some of its strongest proponents have argued that the United States may be about to usher in a new era in which EDR use continues to expand at an exponentlal rate and becomes commonplace in resolving disputes. Jay Hair (1984), Executive Vice President of the National Wildlife Federation, has predicted that more than half of all environmental disputes will be handled through EDR procedures by the year 2000.

But before an era of EDR can or should be proclaimed, this alternative must be exposed to far more careful and critical scrutiny than it has been to date. American environmental policy has a history of lurching from panacea to panacea, in an ongoing search for a regulatory approach that will transform the regulatory system. Perhaps the most recent of these fads has been the variety of strategies designed to apply economic models to environmental policy, such as emissions trading. Oversold initially as an inherently superior form of regulation, these approaches have now come to be seen as far more complicated and suspect than anticipated (Kelman, 1982; Liroff, 1986). They warrant very careful examination before being used more extensively. It is entirely possible that EDR may be on the verge of becoming the next environmental policy panacea. While it may ultimately prove far superior to current methods of dispute resolution, we need to know a great deal more about the contexts in which it does and does not work effectively and the extent to which it advances fundamental objectives such as protection of the environment and human health.

Most prior efforts to analyze EDR have suffered from a variety of limitations. Only a relatively few cases have been completed until recent years, posing obvious research dilemmas. Moreover, very little effort has been made to place existing findings in the context of a politically-oriented theoretical framework that would facilitate longterm analysis as the number of cases grows. Most efforts at theory construction have consisted of fairly general predictors of negotiation 
success; many rely primarily on highly-descriptive case study accounts that lack a tightly-structured comparative case perspective (Susskind, Bacow and Wheeler, 1983; Talbot, 1983; Bacow and Wheeler, 1984). A new generation of research may be forthcoming, along the lines of Gall Bingham's Resolving Environmental Disputes (1986), that establishes some systematic measure of mediation outcome and implementation success for dozens of cases. But we still have far too little evidence to make any other than very general claims about EDR.

The existing literature is also suspect in that many of the leading researchers in this area are also in the vanguard of activists promoting expanded EDR use. Much of what we know empinically about EDR and its effectiveness has been dominated by individuals with a strong normative commitment to EDR, many of whom are professional mediators. This poses enormous conflict of interest problems that call into question the rather upbeat arguments found in many of the leading publications on EDR. It is, in fact, tantamount to basing our understanding of regulatory behavior primarily on the self-analysis of leading regulators, such as former EPA administrators, rather than on intensive and nonpartisan research completed by social scientists without a vested interest in demonstrating regulatory success.

There are also significant limits on the extent to which claims of EDR efficacy can be made on the basis of more extensive research conducted in other policy areas where dispute resolution alternatives are more easily established. Special education mediation, for example, often involves fairly straightforward issues and a common goal of devising the best educational service plan for each child; these are simplifying factors uncommon in environmental disputes (Singer and Nace, 1985). Resolution of claims disputes through mediation involves very specific conflicts between individuals, whereas environmental disputes tend to involve very broad conflicts between groups (McEwen and Malman, 1984). Perhaps the most thoroughly institutionalized and studied area in which alternative dispute resolution has been employed, labor and management relations, may be of limited analogous value to environmental policy (Bingham, 1986:162-163). And in the one study that offers a tramework for comparative analysis of alternative dispute resolution across policy areas, environmental policy was deemed an area in which the potential benefits to society were very high but the chances of success were very low (Marcus, Nadel and Merrikin, 1984:236).

In the absence of a clear understanding of what EDR has accomplished and what can realistically be expected from it, subsequent sections of this paper will outline a variety of potential pitfalls that need to be considered in future deliberations over EDR use and continued expansion. They attempt to raise a number of issues that may pose major stumbling blocks for EDR, but have not yet been 
examined in any systematic way. These sections are drawn heavily from theoretical understandings of American politics and they caution that the American political context may prove incompatible in many respects with alternative methods of dispute resolution in environmental policy.

\section{POTENTIAL POUTICAL IMPEDIMENTS}

Any strategy to expand American reliance on alternative methods for resolving environmental disputes must recognize the realities of the American political system. These realities suggest a well-ingrained pattern of conflictual, highly adversarial institutions and procedures for resolving conflict and establishing policy. Consistent with this is a judicial branch of government that is intended to resolve fundamental conflicts and also serve as co-equal to legislative and executive branches. If not uniquely American features, they are far more firmly established in the United States than other Western democracies where more flexible and consensual, and less judicially-oriented, patterns prevail.

\section{The Absence of Unitary Democracy}

Environmental dispute resolution would be most likely to flourish in a society in which interests were widely presumed to be common and basic patterns of governance were consensual. Such a society is reflected in many political philosophers, including Plato, Aristotle, Rousseau, and Hegel, and may be particularly compatible with certain contemporary non-Western societies. It may even be evident in certain Western democracies, such as those of Austria and the Netherlands, which use consociational (proportional, multi-party) as opposed to majoritarian (winner-take-all, often two-party) electoral methods.

Political philosopher Jane Mansbridge (1983) characterizes a society with consensual pattern of operation as a "unitary" democracy. She acknowledges that unitary democracy can occasionally emerge in American politics, but that it is exceptional to a prevalling pattern of adversarialism. Under "adversarial" democracy, politics approximates a zero-sum game in which interests in both economy and polity are presumed to be in conflict. Through various forms of competition, whether in the marketplace or in a court room, conflicts are resolved and certain interests are elevated above others.

Applied to environmental policy, adversarial democracy would find an array of industrial, governmental, and anti-industry groups with very different interpretations of society's responsibility for environmental protection. Rather than consensually arrive at environmental questions or conflicts, adversarial understandings and procedures would prevail, much as they do at present in the United States. 
Mansbridge's emphasis on American adversarial democracy is consistent with interpretations by other leading social scientists. Robert Bellah and associates, for example, have characterized "utllitarian individualism" as an enduring characteristic of American political life (Bellah, 1985; Auerbach, 1983). With very little emphasis on communitarian responsibilities and little interest in consensual structures of governance, Americans are largely alien to approaches that Mansbridge could characterize as unitarian.

Research that compares environmental policy in the United States and various Western European nations highlights the enduring American penchant for adversarialism. Quite contrary to the more collaborative, consensual pattern of interaction among major groups in the United Kingdom, David Vogel (1986:280) deems adversarialism a basic component of American policy. He notes, for example, that "the most important way in which environmental groups in America 'assist' regulatory agencles in policy implementation is by suing them." His findings are confirmed by additional comparative research that deems American environmental policy far more adversarial than that of France or West Germany (Brickman, Jasanoff and ligen, 1985:270).

Groups that advocate environmental protection might find it particularly difficult to abandon adversarial- and litigation-oriented political strategles. Many such groups have taken full advantage of Iitigation opportunities to attain the maximum political impact with their limited resources. Moreover, some advocate such an adversarial posture as a good investment, as groups are often rewarded with settlement dollars that only bolster their treasuries and make possible future legal battles on other issues (Freudenberg, 1984:166-167).

The American penchant for adversarialism does not preclude the introduction of more unitarian methods for addressing environmental policy. The very emergence of EDR in dozens of specific cases suggests that, consistent with Mansbridge's thesis, unitarian approaches can exist in the same society alongside adversarial ones. Nonetheless, the adversarial culture of American politics and the related nature of its political institutions and processes impose a significant potential threat to any effort to expand EDR.

\section{The Dlsdain Toward Bargaining}

The difficulty of introducing more consensual processes in American policy is compounded by the lack of public trust in the institutions with direct responsibility for protecting the environment and public health. The predominance of open, adversarial procedures of dispute resolution stems in part from an inherent mistrust of political bargaining that is confined to select elites. This is particularly evident in areas such as environmental policy, where potential environmental and health risks are so high and the track record of government and 
industry is so spotty. Environmental issues, in fact, are almost classic examples of the kinds of issues that can be characterized as having unusually high public salience and conflict and attract highly polarized pressure groups (Price, 1979). This salience and conflict may be greater in health-related cases rather than those that focus solely on environmental and natural resource issues. The former may well be the kinds of issues that the American public is least likely to hand over to negotiation, which seeks some form of middle ground. Instead, they may be issues that will be expected to be resolved in public, adversarial settings which seek, at least in theory, the most appropriate policy remedy.

Political bargaining has acquired an especially unsavory quality in the United States in recent decades, reflected in post-Watergate and post-Vietnam reforms that have opened up the American policy-making process to the public. These reforms have included greater citizen access to the courts, mandatory citizen participation in operation of federally funded programs, greater reliance on public hearings in policy formation, and unprecedented disclosure of information, whether through campaign finance reforms or the Freedom of Information Act. This general trend reflects a growing disdain for any semblance of a closed process or political dealing. It differs dramatically from the severe restrictions on public information and access common to more consensual Western European systems Nogel, 1986:92-93). As Wendy Emrich (1984) has observed, there is a danger that environmental mediation "may be seen as a reversion to back room polftical dealing" by limiting the number of participants in dispute resolution and, in many instances, deliberating over public issues in a highly private setting. This is particularly likely in environmental policy, given the unsavory quality of "voluntary compliance" and "negotiation" efforts undertaken by the EPA in the Anne Gorsuch years.

The potential for conflict over restricting public access may well emerge in cases where states have attempted to institutionalize EDR. In Virginia, notes from negotiation of land use planning disputes are exempt from the Freedom of Information Act. This is simllar to negotiation-oriented legislation that has been proposed in other states which also prohibits use of information that emerges from negotiations to be used in any future adjudicatory hearing. Both types of restrictions may be imperative to negotiation success, but run contrary to recent patterns toward openness in public policy.

\section{The Danger of Exclusivity}

Environmental dispute resolution may also run the risk of attracting considerable political opposition in the United States because of its tendency to formally exclude certain groups from participating. By the late 1960s, American environmental legislation 
was under severe attack both for being too lenient on polluters and also for maintaining a highly cooperative and consensual relationship between government and industry. Among the leading goals of major environmental legislation enacted or amended in the 1970 s was the establishment of highly specific standards and procedures that the new EPA would be required to rigorously impose upon industry. This growing rellance on highly exact pollution reduction goals occurred alongside the general opening up of the environmental pollcy process that encouraged formation of a potpourri of pressure groups devoted to environmental and human health protection. Many such groups have made full use of participatory opportunities available in our highly adversarial system. They have greatly influenced policy and have become accustomed to fully participating in every stage of the policy formation process. New procedures designed to promote more consensual resolution of environmental disputes must operate in this context, and somehow find means to incorporate this substantial demand for participation with efforts to create a more stable and consensual process. It is by no means certain that such a blend is possible.

In fact, the consensual procedures so common to Western European "corporatist" societies rely in large part on the capacity to confine negotiation to a relatively small and stable number of wellestablished groups. The process of determining what groups are and are not included tends to reward moderate, compliant groups with participatory opportunities while excluding more strident ones. It also tends to favor industrial and other pollution sources rather than environmental protection advocates (Schmitter and Lehmbruch, 1977; Katzenstein, 1984). This ensures the stability so envied by many observers of pluralistic societies, but runs all the risks of regulatory "capture" by vested industrial groups which has been so vigorously avoided in American environmental policy (Wilson, 1980). And it is particularly dangerous in technically complicated areas such as environmental policy in which industrial groups are likely to have the resources necessary to fund participation and research that opposing groups are likely to lack. It may lead to the potentially significant imbalance in negotiation strength that might be lessened in a more adversarial context. Moreover, opposition groups in a pluralistic society such as the United States are far less likely to receive direct governmental subsidies that curb adversarial tendencies and facilitate meaningful participation, contrary to the common pattern of their subsidization in Western European democracies.

Even as strong an advocate of unitary democracy as Jane Mansbridge (1983:276-277) emphasizes that consensual processes of conflict resolution cannot be embraced uncritically and may lead to less successful results in certain situations. She is particularly concerned 
that policy outcomes from a unitary process may redound to the advantage of the politically strongest negotiation participants. This problem has begun to emerge in Massachusetts, in the case of the state Hazardous Waste Facility Siting Act, which institutionalizes the process of negotiation and is perhaps the most ambitious state legislation to date in this area. It has experienced enormous difficulty in facilitating broad participation and keeping the negotiation process workable. One major concern has been a perceived power imbalance that enables siting opponents to dominate the negotiation process, as their refusal to interact with site developers has thwarted site proposals in the first six cases considered under the Act.

\section{The Demand for Exactitude}

Even if problems of exclusivity were overcome by providing broad and workable participatory opportunities, it is uncertain that proregulatory groups, and the citizenry more generally, would support the shift toward more consensual forms of dispute resolution. American environmental policy is complicated greatly by an extreme public aversion to health-related environmental risk. This aversion may greatly exceed justifiable fear, particularly in comparison to other public health dangers, such as smoking, which may pose a greater health hazard but which fail to trigger comparable alarm. But it is evident in the unusual specificity and stringency with which regulatory standards are set in this area, the extent to which absolutist healthprotection goals are accepted in legislation, and the extensive use of science to measure health ramifications of pollution and guide policy. And in this climate, it might prove very difficult to gain acceptance for consensual procedures that could result in a bargained reduction of commitment to health protection standards. By contrast, environmental disputes lacking a public health dimension might bypass this problem.

The American aversion to environmental health risk is linked to an unusually strong public belief that science can determine risk with precision and thereby mold policy remedies. Rather than trust governmental, industrial, and environmental group leaders to negotiate reasonable regulatory compromises, American environmental policy is uniquely deferential to prevailing scientific thought. Some analysts deem this deference to science excessive and suggest that it may not result in effective regulatory policy (Sapolsky, 1986; Price, 1983). Nonetheless, the political context in which EDR would have to be introduced might prove hostile to any process that emphasized negotiated compromise over science in guiding environmental pollcy.

\section{The Burden of Proving Superior Outcomes}

The ultimate litmus test of any effort to switch from adversarial, court-oriented methods of dispute resolution to more consensual ones 
in the United States will be the outcomes of that process. And yet there is virtually no analysis--and even very little expliclt speculation--concerning the capacity of EDR to deliver more efficacious environmental policy in terms of protecting the environment and human health and doing so in a cost-effective manner. The vast majortty of analysis has focused more generally on the process. It often asserts the inherent superiority of addressing the conflict in a consensual rather than adversarial manner, instead of providing a systematic basis for comparative analysis.

It remains by no means clear that consensual politics inherently leads to better environmental policy. Among political theorists who consider the efficacy of cooperative versus conflictual regimes, it is emphasized that cooperative systems have many attributes but are not without shortcomings. As Duncan Snidal (1985) has noted, "one must be somewhat wary of the presumption that stability-even stabllity of cooperative outcomes--is always a virtue." Conflict theorist James Schellenberg summarizes a general concern raised by many analysts in noting:

The pressures toward unity . . . may have their casualties in decision-making effectlveness. One of the chief casualties is a blased scanning of alternatives for action, selecting only those for attention that are anticipated to have high acceptance by others in the group. The result may well be a group-induced tendency to omit consideration of unusual possibilities of action (Schellenberg, 1982:196). ${ }^{4}$

Such concerns are, of course, very general in nature and have yet to be demonstrated in environmental policy issues resolved through alternative dispute resolution. But they are the types of concerns that will need to be alleviated if EDR is to prove superlor to adversarlal procedures both in terms of providing a more consensual process and in attaining the fundamental goals of environmental policy. They also warrant attention in that other efforts to foster more consensual procedures have proven somewhat disappointing in terms of policy outcomes.

The system of environmental policy so well established in many Western European nations has clearly delivered a more consensual and less expensive process for dispute resolution and policy formation. But there is very little evidence to suggest that this system is more effective in protecting the environment and human health than the American adversarial system. Despite dramatically different systems, neither the United States nor Western Europe has proven particularly effective in addressing serious environmental problems, including acid rain, hazardous and nuclear waste disposal, and toxic substance 
control. Comparative research is scarce but indicates failly similar outcomes despite the fundamental systemic differences. And in certain Western European nations, such as West Germany, a more adversarial approach is emerging in response to growing public unrest over the rellability of their current regulatory systems. Other areas of domestic policy in which prevalling adversarial approaches have been widely lamented further suggest that consensual alternatives do not necessarily offer better policy outcomes (Danzon, 1985:187-195).

\section{CONCLUSION}

This paper has cautioned against any embrace of environmental dispute resolution as a panacea that can be relied upon to cure much of what alls American environmental policy. It acknowledged the shortcomings of our current adversarial approach to dispute resolution and policy formation in this area, but emphasized a number of fundamental qualities of American political life that may mitigate against any effort to employ EDR approaches on a broad scale. Nonetheless, EDR retains considerable promise as a component of environmental regulatory reform in the United States. If not an all-encompassing regulatory remedy that can be easily applied to all disputes, it still may be able to play a profoundly important role in facilitating more mature and effective environmental policy. EDR may best be thought of as one of a series of alternatives to current approaches, one that warrants continued experimentation and analysis that considers the conditions under which it is and is not likely to facilitate consensus and deliver superior policy outcomes.

\section{NOTES}

1. I appreciate funding from the Hewlett Foundation and Program on Conflict Management Alternatives at the University of Michigan that has supported my research on environmental dispute resolution. I also am grateful for the helpful comments on earlier versions provided by Margaret Boone, Tony Citrin, J. Clarence Davies, Lynn Deniston, Robert Katzmann, Philip Mundo, Pam Puntenney, and Kenneth Warner.

2. These states include Massachusetts, Wisconsin, Connecticut, Rhode Island, Texas, and Virginia.

3. These states include Hawaii, Massachusetts, Minnesota, New Jersey, and Wisconsin. See Bingham, 1986:57-58. 
4. A leading analyst of comparative areas of planning and conflict resolution, John Seley has emphasized that "conflict can be a very positive force in society (some argue that it is the one compelling force in true democracies). It should not be viewed only as something to be avoided" (Seley, 1983:15).

\section{REFERENCES}

Auerbach, Jerold S. 1983. Justice Without Law? (New York: Oxford University Press).

Bacow, Lawrence S. and Michael Wheeler. 1984. Environmental Dispute Resolution (New York: Plenum).

Bellah, Robert, et al. 1985. Habits of the Heart (Berkeley, CA: University of California Press).

Bingham, Gail. 1986. Resolving Environmental Disputes: A Decade of Experience (Washington, DC: Conservation Foundation).

Brickman, Ronald, Shiela Jasanoff, and Thomas Ilgen. 1985. Controlling Chemicals: The Politics of Regulation in Europe and the United States (Ithaca, NY: Comell University Press).

Daneke, Gregory A. 1984. "Whither Environmental Regulation?" Journal of Public Policy 4(2):139-151.

Danzon, Patricla M. 1985. Medical Malpractice: Theory, Evidence, and Public Policy (Cambridge, MA: Harvard Universtty Press).

Downing, Paul B. 1983. "Bargaining and Pollution Control." Policy Studies Review 11:577-586.

Emrich, Wendy. 1984. Remarks to Second National Conference on Environmental Dispute Resolution, Conservation Foundation, Washington, DC, October 1, 1984.

Freudenberg, Nicholas. 1984. NOT In Our Backyards! Community Action for Health and the Environment (New York: Monthly Review Press).

Fuller, Lon L. 1981. "The Forms and Limits of Adjudication." Pp. 87124 in Kenneth I. Winston, ed., The Principles of Social Order (Durham, NC: Duke University Press). 
Gusman, Sam and Philip J. Harter. 1986. "Mediating Solutions to Environmental Risks." American Review of Public Health 7:306-310.

Hair, Jay D. 1984. "Getting Ready to Win." Address to Second National Conference on Environmental Dispute Resolution, Conservation Foundation, Washington, DC, October 2, 1984.

Heclo, Hugh. 1977. A Government of Strangers (Washington, DC: The Brookings Institution).

Katzenstein, Peter J. 1984. Corporatism and Change (Ithaca, NY: Cornell University Press).

Kelman, Steven. 1982. What Price Incentives? (Boston: Auburn House).

Lleberman, Jethro. 1981. The Litigious Society (New York: Basic Books).

Liroff, Richard A. 1986. Reforming Air Pollution Regulation: The Toil and Trouble of EPA's Bubble (Washington, DC: Conservation Foundation).

Mansbridge, Jane J. 1983. Beyond Adversarial Democracy, 2nd ed. (Chicago: University of Chicago Press).

Marcus, Alfred A. Mark V. Nadel, and Karen Merrikin. 1984. "The Applicability of Regulatory Negotiation to Disputes Involving the Nuclear Regulatory Commission." Administrative Law Review 36(Summer):236.

McEwen, Craig A. and Richard J. Maiman. 1984. "Mediation in Small Claims Court: Achieving Compliance Through Consent." Law \& Society 18(1):41.

Melnick, R. Shep. 1983. Regulation and the Court: The Case of the Clean Air Act (Washington, DC: The Brookings Institution).

Price, David E. 1979. Policymaking in Congressional Committees: The Impact of 'Environmental' Factors (Tucson, AZ: University of Arizona Press).

Price, Donald K. 1983. America's Unwritten Constitution: Science, Religion, and Political Responsibility (Cambridge, MA: Harvard University Press). 
Ruckelshaus, William D. 1984. Address to Second National Conference on Environmental Dispute Resolution, Conservation Foundation. Washington, DC, October 1, 1984.

Sapolsky, Harvey, ed. 1986. Consuming Fears: The Politics of Consumer Risk (New York: Basic Books).

Schellenberg, James A. 1982. The Science of Conflict (New York: Oxford University Press).

Schmitter, Phillippe C. and Gerhard Lehmbruch, eds. 1977. Trends Toward Corporatist Intermediation (Beverly Hills, CA: Sage).

Schuck, Peter H. 1987. Agent Orange on Trial (New Haven, CT: Yale University Press).

Seley, John E. 1983. The Politics of Public-Facility Planning (Now York: D.C. Heath).

Singer, Linda R. and Eleanor Nace. 1985. Mediation in Special Education: Two States' Experiences (Washington, DC: National Institute for Dispute Resolution).

Snidal, Duncan. 1985. "Coordination Versus Prisoner's Dilemma: Impllcations for International Cooperation and Regimes." American Political Science Review 79:939.

Susskind, Lawrence, Lawrence Bacow, and Michael Wheeler, eds. 1983. Resolving Environmental Regulatory Disputes (Cambridge, MA: Schenkman).

Susskind, Lawrence and Gerard McMahon. 1985. "The Theory and Practice of Negotiated Rulemaking." Yale Journal on Regulation 2:133-165.

Talbot, Allan. 1983. Sertling Things Washington, DC: Conservation Foundation).

Vogel, David. 1986. National Styles of Regulation: Environmental Policy in Great Britain and the United States (Ithaca, NY: Cornell University Press).

Wilson, James Q. 1980. "The Politics of Regulation." In James Q. Wilson, ed., The Politics of Regulation (New York: Basic Books). 
This document is a scanned copy of a printed document. No warranty is given about the accuracy of the copy. Users should refer to the original published version of the material. 